\title{
Back to Medical Ethics
}

\section{Welles JF*}

P O Box 17 East Marion, NY 11939, USA

Opinion

Volume 4 Issue 1

Received Date: February 03, 2021

*Corresponding author: James F Welles, P O Box 17 East Marion, NY 11939, USA, Tel: 954531-5382; Email: JWelles103@aol.com
Published Date: February 09, 2021

DOI: $10.23880 /$ jqhe-16000204

\section{Opinion}

Although nobody much reads the original Hippocratic Oath any more, it is essentially a commitment to keeping trade secrets. The modern version focuses on not taking advantage of patients sexually while providing medical care directed toward their health and well-being. Unfortunately, it does not address the current, rampant corruption of financial abuse which the insurance industry imposes on American physicians. How many time a day does a doctor provide services which are not necessary for the patient's health?.

It is called "Padding the bill" by anyone else, and it is unethical by any medical standard. If Hippocrates did honor the ageless maxim, "Do the patient no harm", that principle today should be extended beyond the patient's medical condition to his/her financial condition as well. The sad fact is, the overwhelming proportion of physicians have sold their souls to insurance companies which are unabashedly dedicated to ripping off the patients and the government, which compliantly goes along with the scam.

It is time for physicians to band together and form their own insurance company grounded on the principle of providing only medically essential services and charging minimal rates for them. Once established, doctors would flock to it, leaving the money-grubbers with their pockets turned out on the outside looking in.

It is time for ethical physicians to take back financial control of their profession. This is how to do it. Every physician who is committed to the patient's health and wellbeing rather than to over charging for the sake of running up a bill is invited to post the following announcement in his/ her office:

All medical procedures performed in this office by the undersigned physicians and their staff is necessary for the health and wellbeing of the patients. Any procedures mandated by law as a result of lobbying by the state Medical Association which are not necessary for the patient's health and well-being will be performed free of charge.

Not a single dollar charged by this office will go to an insurance company. All funds go to support a medical staff devoted to providing you the best care possible at the lowest cost.

\section{We are here for you}

The idea is that the physician's conscience will replace the insurance companies in terms of deciding what treatment will be provided. Physicians will do what they should rather than what they can get away with just to run up a bill on government payment programs-Medicare/Medical, etc. Let's put the "Should" back in medicine.

I believe all members of a health team would be proud to sign the above statement. I believe physicians committed to this program of action will drive the others out of business because they will undercut the unscrupulous physicians who are in business for themselves and insurance companies. 